\title{
The Radiocarbon Chronology of the Norfolk Island Archaeological Sites
}

\author{
Atholl Anderson ${ }^{1}$, TOM Higham ${ }^{2}$ AND Rod WALlacE ${ }^{3}$ \\ ${ }^{1}$ Department of Archaeology \& Natural History, Research School of Pacific and Asian Studies, \\ Australian National University, Canberra ACT 0200, Australia \\ aja@coombs.anu.edu.au \\ ${ }^{2}$ Waikato Radiocarbon Laboratory, University of Waikato, Hamilton, New Zealand. \\ Current address: Oxford Radiocarbon Accelaration Unit, University of Oxford, United Kingdom \\ thomas.higham@archaeology-research.oxford.ac.uk \\ ${ }^{3}$ Department of Anthropology, University of Auckland, Private Bag 92019, Auckland, New Zealand \\ r.wallace@auckland.ac.nz
}

\begin{abstract}
Radiocarbon determinations were obtained for archaeological sites at Cemetery Bay and Emily Bay, Norfolk Island. Sample materials were rat bone gelatin, marine shell and wood charcoal. Ages on bone gelatin are contradictory and suggest a laboratory problem, while ages on marine shell appear to include an old-carbon offset of 500-600 years: dates on these samples are consistent with those on charcoal when appropriate corrections are made. Ages on charcoal were divided according to the expected inbuilt age of the sample taxa. The samples with lowest inbuilt age were subjected to Bayesian analysis which concluded that the main archaeological site, at Emily Bay, had been occupied from the early thirteenth to the early fifteenth centuries A.D. The Norfolk Island settlement occurs within the same age range as other Polynesian settlements of southern islands.
\end{abstract}

Anderson, Atholl, Tom Higham And Rod Wallace, 2001. The radiocarbon chronology of the Norfolk Island archaeological sites. In The Prehistoric Archaeology of Norfolk Island, Southwest Pacific, ed. Atholl Anderson and Peter White, pp. 33-42. Records of the Australian Museum, Supplement 27. Sydney: Australian Museum.

Radiocarbon determinations have been obtained from two archaeological sites on Norfolk Island: Cemetery Bay and Emily Bay. In both cases, multiple sample types were dated. Each type of sample is associated with different issues of processing and interpretation so we consider them first in these categories. Following that, we discuss the chronologies in their stratigraphic and spatial contexts and then consider the age of prehistoric settlement on Norfolk Island generally and in relation to the prehistoric chronologies of archipelagos which might have contributed colonists.

\section{Charcoal identification}

The first results from Norfolk Island (Rich et al., 1983: 17) were on unidentified charcoal (I-11019, I-11303, Table 6) from excavations at Cemetery Bay. Additional excavations there by Meredith (1985: 22) added two samples (Beta6821, Beta-6822) comprising pieces from "small branches" (3-4 cm diameter) of gymnosperm, almost certainly Norfolk pine (Araucaria heterophylla). It is not clear how branchwood was identified (deduction from the curvature 
of growth rings is open to alternative interpretations), and there are other reasons (below) that recommend caution, so the assumption that these results are good estimates of the age of the Cemetery Bay deposit remains open to question, for reasons outlined below.

The first four samples from the Norfolk Island Prehistory Project (NIPP) 1995 excavations (ANU-10157 to ANU10160, Table 6) were identified no more certainly. Two were of Araucaria sp., and two of other but unidentified wood. From the NIPP 1996 season, it was possible to isolate material which was entirely of broadleaf taxa. In the NIPP 1997 season, Wallace (1998) made a collection of comparative material from all 33 indigenous woody plants on Norfolk Island (Orchard and Thompson, 1999) from which he was able to identify charcoal samples to species.

The wood samples were made into thin sections showing each of the three planes of each sample, and from those were made photomicrographs which allowed identification to the species level. Charcoal samples were snapped across the grain and cloven along it, and the faces observed under incident illumination using a compound microscope at magnifications of 50-500 diameters. Identifications were made by comparing the cell patterns with the samples from the comparative collection.

Wallace (1998) examined 99 bags of charcoal (about 2.5 $\mathrm{kg}$ ) from the 1997 trenches, two from EB97:21, one from EB97:22, 78 from EB97:23 and 18 from EB97:24. In general, about $75 \%$ of the charcoal in each bag could be identified, the remainder being of pieces too small to process. The objective was to obtain samples of identified broadleaf material weighing a minimum of $6 \mathrm{~g}$ to enable high precision Liquid Scintillation radiocarbon dating. This was achieved relatively rarely. Broadleaf charcoal samples of $6 \mathrm{~g}$ or more were found once in EB97:21, in 38 of the 78 bags from EB97:23 and in none of the EB97:21 or EB97:24 bags. In the latter trench, only $12.5 \mathrm{~g}$ of broadleaf charcoal was obtained from the entire collection.

The most striking aspect of the assemblage is that $95 \%$ of the charcoal by weight was from Norfolk pine. Even if that was the dominant emergent tree, as it was historically in the Kingston area, it probably would not have provided $95 \%$ of the available firewood, except if the inhabitants chose to ignore material from other kinds of trees, which seems improbable. It is more likely that much of the charcoal in the site is from burnt-down structures, such as houses or cooking sheds, which had been built from the long, straight branches of Norfolk pine. Certainly, the postbutts left in EB97:23 were all of Norfolk pine branches (Wallace 1998).

Unfortunately, this is a poor material for accurate radiocarbon dating because its mode of growth presents a high probability of significant inbuilt age (i.e. the wood was dead, and stored in the trunk or branches, for a long time before it was used as firewood-McFadgen, 1982). Norfolk pine grows quickly to form massive, cylindrical trunks with regular radial outgrowths of branches which persist during the life of the tree and expand only very slowly in diameter. Consequently, not only is trunkwood likely to be several hundred years old or more, but so is branchwood. Measurements on carbonized branchwood disclose up to two annual growth rings per $\mathrm{mm}$, so that even quite small branches can have significant inbuilt age.

The identification of Metrosideros sp. (pohutukawa) is interesting, because it is not native to Norfolk Island
(Wallace, 1998). It is possible that some charcoal from recently-introduced Metrosideros excelsa has managed to get into the site, but it was found in two excavation areas and it may indicate either the former existence of a native Metrosideros sp. on Norfolk Island (it is a prominent native on Raoul Island and Lord Howe Island), or the prehistoric introduction of the genus. The charcoal could have come as Metrosideros timber in prehistoric artefacts, such as canoe components, or Metrosideros sp. may have been brought as seeds. Wallace (1998) points out that Metrosideros kermadecensis is dominant on Raoul Island, existing as an almost pure forest over the Low Flat site (Anderson, 1980); any soil around plants carried from Raoul would probably contain Metrosideros seed, which is highly abundant, and seed would have ended up in any canoe pulled up on the Low Flat foreshore. Metrosideros might have grown at Kingston around the Polynesian settlement, perhaps then dying out as the Norfolk pine forest reclaimed the abandoned site.

The distribution of the charcoal samples amongst broadleaved taxa (Table 1) shows that 20 of the 33 woody plants native to Norfolk Island occur in the Emily Bay charcoals. These indicate the existence of a mixed coastal forest of trees and shrubs. The main species in the charcoals (with common name and maximum height) were Nestegis apetala (Ironwood, $6 \mathrm{~m}$ ), Rapanea ralstoniae (Beech, $6 \mathrm{~m}$ ), Elaeodendron curtipendulum (Maple, $13 \mathrm{~m}$ ), Ungeria floribunda (Bastard oak, $15 \mathrm{~m}$ ) and Baloghia inophylla (Bloodwood, $7 \mathrm{~m}$ ). Bastard oak is quite rare today, whereas white oak (Lagunaria patersonia) which is common today and grows under the Norfolk pine forest at Emily Bay, is fairly rare in the charcoal samples.

On the basis of the taxonomic identifications it is possible to divide the charcoal samples used for radiocarbon determination into three groups. Group A comprises samples

Table 1. Distribution of charcoal samples and pieces by identified broadleaf taxa at Emily Bay.

\begin{tabular}{rcc}
\hline broadleaf taxa & $\begin{array}{c}\text { number of } \\
\text { charcoal } \\
\text { samples }\end{array}$ & $\begin{array}{c}\text { number of } \\
\text { charcoal } \\
\text { pieces }\end{array}$ \\
\hline $\begin{array}{r}\text { Rapanea ralstoniae } \\
\text { Elaeodendron curtipendulum }\end{array}$ & 18 & 87 \\
Ungeria floribunda & 15 & 78 \\
Baloghia inophylla & 14 & 50 \\
Nestegis apetala & 13 & 49 \\
Dodonaea viscosa & 7 & 123 \\
Myoporum obscurum & 6 & 18 \\
Lagunaria patersonia & 5 & 29 \\
Melicytus ramiflorus & 4 & 13 \\
Dysoxylum bijugum & 3 & 16 \\
Pennantia endlicheri & 2 & 28 \\
Excoecaria agallocha & 2 & 3 \\
Streblus pendulinus & 2 & 3 \\
Sarcomelicope simplicifolia & 2 & 2 \\
Celtis paniculata & 1 & 3 \\
Melicytus latifolius & 1 & 1 \\
Pittosporum bracteolatum & 1 & 2 \\
Melicope littoralis & 1 & 1 \\
Coprosma pilosa & 1 & 1 \\
Rhopalostylis baueri & 1 & 1 \\
Metrosideros sp. & 4 & 20 \\
\hline
\end{tabular}


in which the charcoal is all from broadleaved taxa and derived predominantly from small tree or shrub species, plus shoots of Norfolk pine twigs (Table 2). Group B samples are of broadleaved taxa which are either unidentified to genera or are identified as being from larger tree species (Table 2). Group C samples are of Norfolk pine or unidentified charcoal.

\section{Radiocarbon determinations on charcoal samples}

Over the past decade there have been significant developments in radiocarbon age calibration, culminating in the publication of the 1998 INTCAL calibration curves (Stuiver et al., 1998) which enable calibration from 0-24,000 cal B.P. In addition, there has been a growing awareness of the importance of careful sample selection in archaeological dating and the combination of radiocarbon determinations with prior archaeological knowledge, in the form of stratigraphic and contextual information (Buck et al., 1996). In the dating of the Norfolk Island contexts, we were interested particularly in issues of occupation span and the evidence for earliest human occupation at the excavated site at Emily Bay.

We used the BCal calibration programme (Buck et al., 1999) to help us to answer these questions of chronology in more detail. BCal enables relative archaeological a priori information (relative stratigraphy and archaeological provenance) to be used in association with radiocarbon determinations, within a Bayesian statistical paradigm (Buck et al., 1996).

We developed a calibration model (see Figs. 1, 5) in BCal to evaluate the chronology at the Emily Bay EB97:23 and EB97:24 trenches. These two trenches yielded the majority of the Group A samples. In the model, certain mathematical symbols are used to describe the stratigraphic phases and boundaries at the site. $\alpha_{n}$ and $\beta_{n}$ represent the beginning and ending dates of phase $n . \alpha_{1}$ therefore represents the period preceding human occupation, while the late phase boundary of Spit 2 is represented by $\beta_{4}$ (Fig. 1).

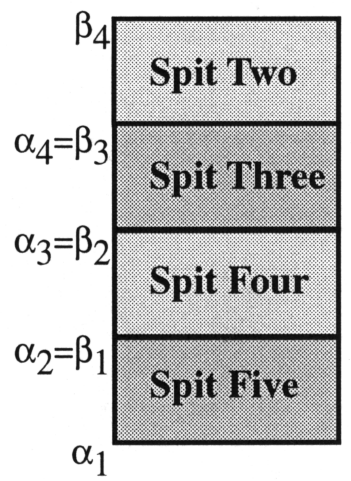

Figure 1. Calibration model for Trench EB97:23 at Emily Bay, Norfolk Island.

The calendar dates associated with individual radiocarbon determinations (termed $\theta_{1} \ldots \theta_{n}$ ) (Table 3) from Trench EB97:23 were modelled within the constraints imposed by four stratigraphic phases, or spits. Spits 2, 3, 4 and 5 were modelled in BCal as abutting phases of shallow depth. Within each single spit, the radiocarbon determinations were assumed to be contemporary. The calibration model was run three times with a Markhov Chain Monte Carlo (MCMC) sampler of 50,000 iterations collected at a sampling interval of 50 (Buck et al., 1996).

Table 2. Charcoal composition of Group A and Group B samples from Emily Bay.

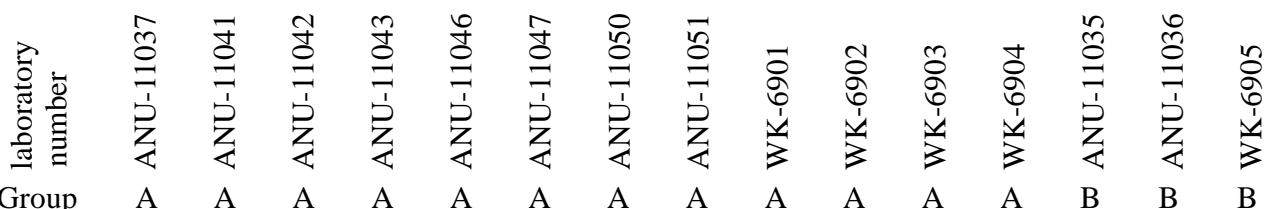

charcoal Group

\begin{tabular}{|c|c|c|c|c|c|c|c|c|c|c|c|c|c|c|c|}
\hline \multicolumn{16}{|l|}{ broadleaf taxa } \\
\hline Ungeria floribunda & - & - & 2 & - & - & - & 3 & 6 & - & 5 & 3 & 3 & 2 & 2 & 7 \\
\hline Lagunaria patersonia & - & - & - & 3 & 2 & - & - & - & 3 & - & 3 & - & 2 & - & - \\
\hline Elaeodendron curtipendulum & - & - & 3 & 2 & 9 & 4 & - & - & 2 & 6 & 4 & - & 12 & 11 & - \\
\hline Pennantia endlicheri & - & - & - & - & - & - & - & - & - & - & - & - & - & 1 & - \\
\hline Celtis paniculata & - & - & - & 3 & - & - & - & - & - & - & - & - & - & - & - \\
\hline Metrosideros sp. & - & - & - & - & - & - & - & - & - & - & - & - & 6 & 5 & 3 \\
\hline Baloghia inophylla & 6 & - & 5 & 1 & 2 & 7 & - & 6 & - & - & 3 & 2 & 7 & 1 & - \\
\hline Nestegis apetala & 3 & 1 & - & 20 & - & - & - & - & 30 & 25 & 12 & - & 3 & - & 3 \\
\hline Dodonaea viscosa & - & - & - & - & - & - & - & - & - & 7 & 1 & - & 2 & - & - \\
\hline Myoporum obscurum & - & 15 & - & 2 & 5 & - & 2 & 3 & - & - & - & - & - & - & - \\
\hline Rapanea ralstoniae & 1 & 4 & 10 & 3 & 15 & 6 & - & - & - & - & 3 & - & - & - & 3 \\
\hline Melicytus latifolius & - & - & - & - & - & - & - & - & - & - & 1 & - & - & - & - \\
\hline Dysoxylum bijugum & - & - & - & - & - & - & - & - & - & - & - & 25 & - & - & - \\
\hline Streblus pendulinus & - & - & - & - & - & - & - & 3 & - & - & - & - & - & - & 1 \\
\hline Pittosporum bracteolatum & - & - & - & - & - & - & 2 & - & - & - & - & - & - & - & - \\
\hline Coprosma pilosa & 1 & - & - & - & - & - & - & - & - & - & - & - & - & - & - \\
\hline Melicope littoralis & - & - & - & - & - & - & - & - & - & - & 1 & - & - & - & - \\
\hline Rhopalostylis baueri (seed) & - & - & - & - & - & - & - & - & - & - & 1 & - & - & - & - \\
\hline Norfolk pine twig & - & - & - & - & - & - & - & 4 & - & - & - & 3 & - & - & - \\
\hline
\end{tabular}


Table 3. Individual posterior date calendar distributions for each determination from EB97:23, as simulated in BCal. The HPD regions given are at $95 \%$ probability and are rounded to five years.

\begin{tabular}{cll}
\hline $\begin{array}{c}\text { calendar } \\
\text { date }\end{array}$ & $\begin{array}{c}\text { laboratory } \\
\text { number }\end{array}$ & \multicolumn{1}{c}{ HPD region } \\
\hline$\theta_{1}$ & ANU-11043 & A.D. $1065-1080,1125-1135,1160-1295$ \\
$\theta_{2}$ & Wk-6902 & A.D. $1240-1315$ \\
$\theta_{3}$ & Wk-6903 & A.D. 1245-1320 \\
$\theta_{4}$ & ANU-11037 & A.D. 1275-1335, A.D. 1340-1380 \\
$\theta_{5}$ & Wk-6901 & A.D. 1275-1330, A.D. 1345-1385 \\
$\theta_{6}$ & ANU-11042 & A.D. 1295-1330, A.D. 1340-1400 \\
$\theta_{7}$ & ANU-11041 & A.D. 1300-1415 \\
$\theta_{8}$ & ANU-11051 & A.D. 1300-1435 \\
$\theta_{9}$ & ANU-11046 & A.D. 1300-1445 \\
\hline
\end{tabular}

Prior to the analysis of the radiocarbon determinations, we hypothesized that the variation in Norfolk Island radiocarbon determinations upon charcoal samples might be related to inbuilt age. We therefore applied an outlier analysis to the Group A radiocarbon dataset at EB97:23 at Emily Bay to consider whether there were grounds for considering some determinations as affected by inbuilt age. We ascribed a prior outlier probability of $10 \%$ to each radiocarbon determination. With the exception of ANU11042 (780 \pm 70 B.P.) which produced an posterior probability of $12 \%$, the determinations were less than the $10 \%$ prior outlier applied. We concluded therefore that there are no outliers of significance.

The Group A results for EB97:23 span 790-530 B.P. (Table 4). We examined the group boundary parameters (early and late) for the determinations from each of the four stratigraphic components in this trench. These parameters represent the calibrated ages for the start and end of the groups. The posterior probability density for the earliest date of human occupation at this area of the site is represented by $\alpha_{1}$. The most likely calendar date range (or ranges) for each parameter outlined in Fig. 1 are represented by highest posterior density (HPD) regions. The HPD region for $\alpha_{1}$ at $95 \%$ is 1520 B.C. to A.D. 1295 , with a modal value of A.D. 1220 (see Fig. 2). The modal value is the calendar age associated with the highest probability value. The terminus of occupation at the site is represented by $\beta_{4}$. The range for this parameter is A.D. 1300-1540 with a modal value of A.D. 1410 (Fig. 3). The overall range for occupation inferred for the EB97:23 area at 95\% is 55-3,000 years, with 200 years yielding the highest probability (Fig. 4).

There are four Group A radiocarbon determinations from Trench EB97:24 (Table 4). The calibration model for these is shown in Fig. 5. The individual conventional radiocarbon ages support an occupation dating to the late thirteenth to fourteenth centuries A.D. A Bayesian analysis suggests a total elapsed occupation span of 10-2,740 years, with the highest probability (modal value) at 100 years (Fig. 6). The range for $\alpha_{1}$ was 1350 B.C. to A.D. 1390 with a modal value of A.D. 1300. This represents the earliest likely date for human occupation given the present data. Taken together, the analysis supports an occupation which began after A.D. 1300 and lasted for about a century. Confidence in this interpretation is reduced by the small number of dated samples from this area.

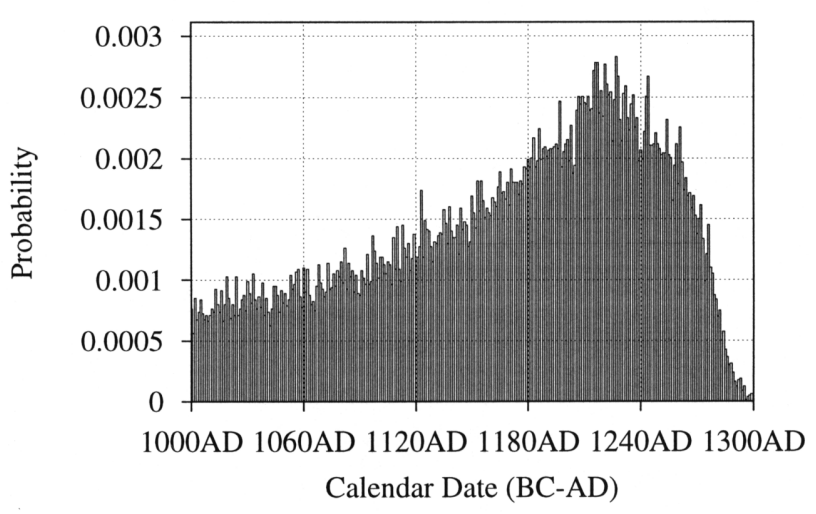

Figure 2. Posterior probability distribution for $\alpha_{1}$ at EB97:23.

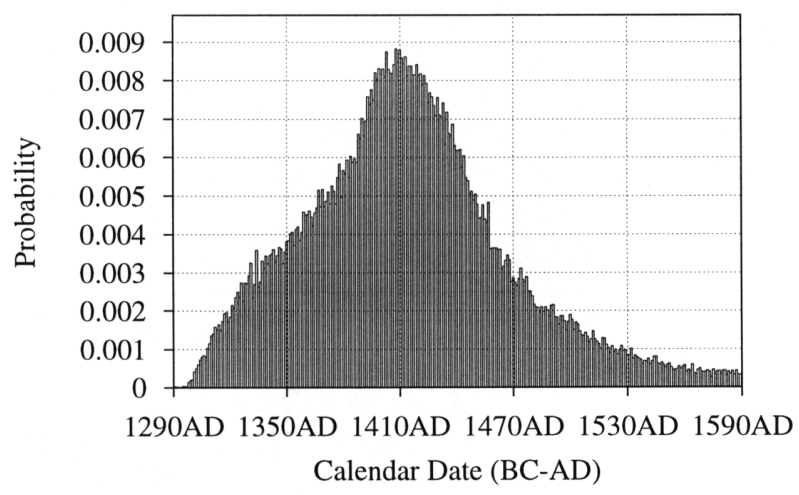

Figure 3. Posterior probability distribution region for $\beta_{4}$.

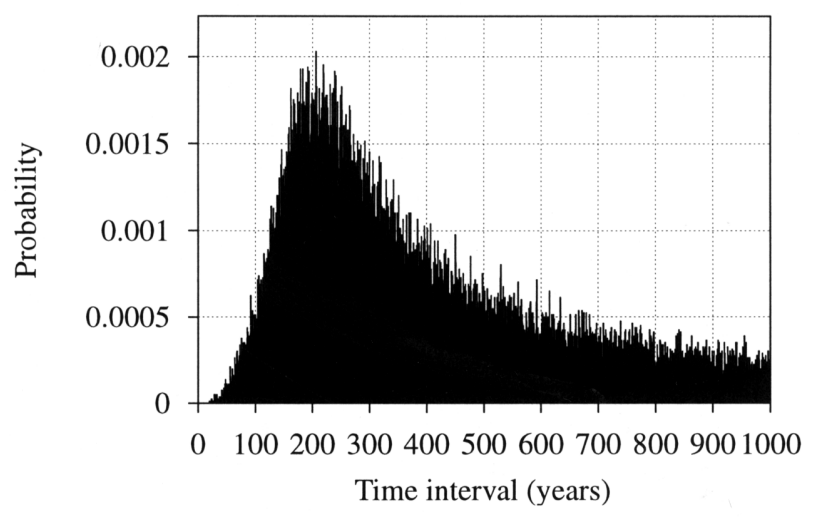

Figure 4. Total elapsed occupation span for cultural horizons at EB97:23, $\alpha_{1}-\beta_{4}$.

Group B results from several trenches at the Emily Bay site are on material which could contain a higher inbuilt age. They are more variable, with the conventional radiocarbon ages spanning 400 radiocarbon years, three of them older than 800 B.P. (Table 5). Group C results are on material from Cemetery Bay and Emily Bay which, at least where it is identified as Norfolk pine, is likely to be significantly in error by reason of inbuilt age. They are the most variable of results, with conventional ages spanning 650 radiocarbon years, six of them older than 800 B.P. and three younger than 500 B.P. (Table 6). The young determinations remain enigmatic. They are too old to be 
Table 4. Group A radiocarbon determinations from Emily Bay.

\begin{tabular}{rlclll}
\hline lab number & trench & square/spit & CRA(B.P.) & $\delta^{13} \mathrm{C}$ & calibrated 1SD (A.D.) \\
\hline ANU-11037 & EB97:23 & Square B7 Spit 3 & $790 \pm 120$ & $-24 \pm 2$ & $1162-1300$ \\
ANU-11042 & EB97:23 & Square C7 Spit 2 & $780 \pm 70$ & $-24 \pm 2$ & $1217-1290$ \\
ANU-11041 & EB97:23 & Square D6 Spit 2 & $670 \pm 80$ & $-24 \pm 2$ & $1281-1398$ \\
ANU-11046 & EB97:23 & Square E7 Spit 2 & $530 \pm 70$ & $-24 \pm 2$ & $1327-1333,1395-1441$ \\
ANU-11043 & EB97:23 & Square E10 Spit 5 & $760 \pm 70$ & $-24 \pm 2$ & $1225-1295$ \\
WK-6902 & EB97:23 & Square E12 Spit 4 & $750 \pm 45$ & $-26.0 \pm 0.2$ & $1255-1292$ \\
WK-6901 & EB97:23 & Square F10 Spit 3 & $720 \pm 45$ & $-26.2 \pm 0.2$ & $1277-1299$ \\
WK-6903 & EB97:23 & Square F10 Spit 4 & $710 \pm 45$ & $-24.6 \pm 0.2$ & $1280-1301$ \\
ANU-11051 & EB97:23 & Square A1 Spit 2 & $570 \pm 70$ & $-24 \pm 2$ & $1307-1361,1378-1431$ \\
OxA-9629 & EB97:24 & Square A5 Spit 2 & $621 \pm 31$ & $-26.6 \pm 0.3$ & $1304-1370,1370-1398$ \\
ANU-11050 & EB97:24 & Square A6 firepit/posthole & $540 \pm 90$ & $-24 \pm 2$ & $1310-1354,1385-1444$ \\
ANU-11047 & EB97:24 & Squares B1 \& B2 Spit 3 & $590 \pm 110$ & $-24 \pm 2$ & $1293-1436$ \\
WK-6904 & EB97:24 & Square B4 Spit 2 & $740 \pm 55$ & $-24.3 \pm 0.2$ & $1256-1297$ \\
\hline
\end{tabular}

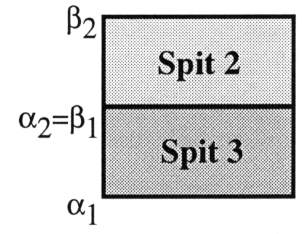

Figure 5. Calibration model for Trench EB97:24 at Emily Bay, Norfolk Island.

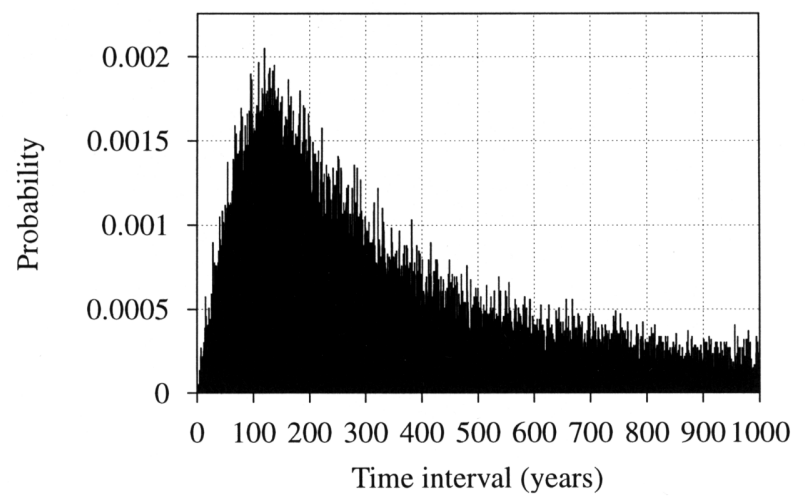

Figure 6. Total elapsed occupation span for cultural horizons at EB97:24; $\alpha_{1}-\beta_{2}$.

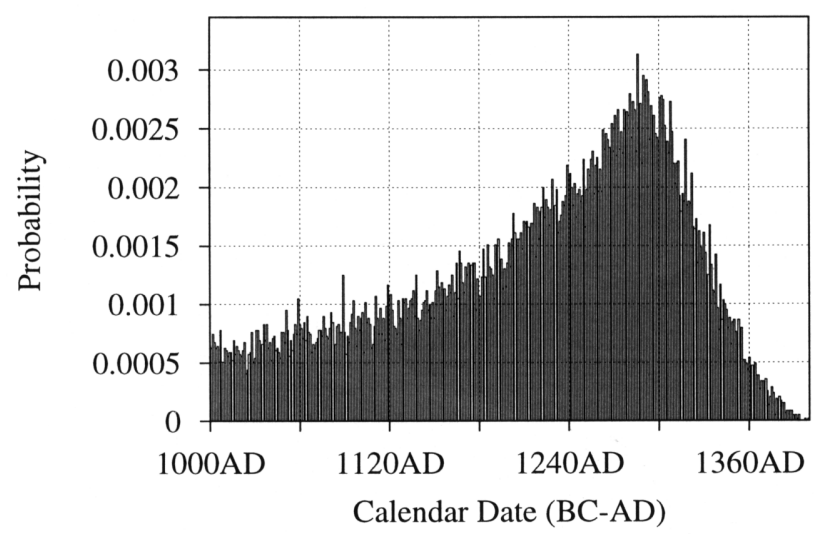

Figure 7. Posterior probability distribution of $\alpha_{1}$ from EB97:24. from European settlement and inbuilt age cannot be a significant variable in their measured ages since this influences radiocarbon determinations to be older, rather than younger. Whether they represent the last flickerings of the main prehistoric occupation, some later-arrived settlers, or are derived naturally from post-occupational forest fires, cannot be determined with confidence.

Neither Group B nor Group C samples were calibrated with $\mathrm{BCal}$ because of the sample constituent problems and the small numbers of dated samples from stratigraphically defined features. We conclude that the radiocarbon results for Group A samples from Trench EB97:23 are the most reliable since they are the largest and best identified assemblages of radiocarbon determinations for the excavation at Emily Bay. They provide support for an occupation which began in the thirteenth century A.D. The nature of the site suggests a brief period of occupancy, but this is not supported by the radiocarbon determinations which span 790-530 B.P., and suggest the highest probability associated with a period of c. 200 years of occupation from first settlement. This may imply that inbuilt age, even amongst the Group A samples, is still a significant influence in spreading the ages determined. Alternatively, it may suggest a more extensive span of occupation in prehistory than expected.

\section{Radiocarbon determinations on marine shell}

Determinations on marine shell samples are listed in Table 7. All of the determinations were from Nerita atramentosa, the most common shell species in the Emily Bay site. Nerita is an herbivorous grazing gastropod of the upper tidal zone, probably taken in largest numbers from the calcreted sandstone shore rock and tidal reef at Emily Bay. One question which arises regarding the marine shell series from Norfolk Island is the size of the marine reservoir offset. Radiocarbon assays of marine shell may be calibrated using the marine calibration curve which uses a box diffusion model based on the atmospheric ${ }^{14} \mathrm{C}$ record to determine an average world ocean curve (which incorporates a 400 year reservoir), from which local offsets $(\Delta \mathrm{R})$ can then be applied (Stuiver et al., 1998). In the absence of samples of knownage shell from Norfolk Island, the value for $\Delta \mathrm{R}$ must be set to $0 \pm 0 \mathrm{yr}$, which assumes that the reservoir of surface ocean 
Table 5. Group B radiocarbon determinations from Emily Bay.

\begin{tabular}{rlllll}
\hline lab number & trench & Square/Spit & CRA(B.P.) & $\delta^{13} \mathrm{C}$ & calibrated 1 SD (A.D.) \\
\hline ANU-10701 & EB96:10 & Square A5 Spit 1 & $830 \pm 60$ & $-24 \pm 2$ & $1168-1278$ \\
ANU-10702 & EB96:10 & Square A5 Spit 2 & $730 \pm 70$ & $-24 \pm 2$ & $1251-1303$ \\
ANU-10703 & EB96:10 & Square B1 Spit 1 & $710 \pm 70$ & $-24 \pm 2$ & $1276-1377$ \\
ANU-10704 & EB96:11 & Square A1 Spit 1 & $1,010 \pm 110$ & $-24 \pm 2$ & $898-907,961-1165$ \\
ANU-10705 & EB96:11 & Square A1 Spit 2 & $610 \pm 70$ & $-24 \pm 2$ & $1298-1409$ \\
ANU-11035 & EB97:21 & Square Z2 Spit 1 & $800 \pm 70$ & $-24 \pm 2$ & $1192-1286$ \\
ANU-11036 & EB97:21 & Square Z2 Spit 2 & $760 \pm 70$ & $-24 \pm 2$ & $1225-1295$ \\
WK-6905 & EB97:24 & Square C3 Spit 2 & $830 \pm 75$ & $-25.6 \pm 0.2$ & $1163-1281$ \\
\hline
\end{tabular}

waters in this region is typical of the average world ocean. Calibrating marine shell under these circumstances might involve a degree of error, because the local reservoir may be significantly different from the average world ocean value due to upwelling effects, for instance. One means of testing this is to radiocarbon date samples of known-age shell from the pre-bomb (earlier than A.D. 1950) reservoir and ascertain the size of the offset. In the absence of knownage shell, an alternative is to date stratigraphically identical marine and terrestrial samples, and determine the offset between them. In this instance, radiocarbon determinations of charcoal and Nerita shell from similar contexts produced ages at odds with that expected, with Nerita older by up to about 600 years. Why?

Marine and estuarine shellfish construct calcium carbonate within a small gap between the shell mantle and the body of the organism. Calcium and bicarbonate $\left(\mathrm{HCO}_{3}\right)$ are taken up by the organism from external sources, with the $\mathrm{HCO}_{3}$ usually dominated by dissolved inorganic carbon (DIC) in the ocean water, as well as metabolic carbon from ingested marine microorganisms or algae. $\mathrm{CaCO}_{3}$ is deposited from within the extrapillial fluid in the inner shell mantle. Determining the source, or sources, of carbon for shell carbonate precipitation is important in determining whether a marine shell is likely to prove reliable for routine radiocarbon assay.

One source of uncertainty in the dating of shell from Norfolk Island is the presence of calcareous rock substrates (that are radioactively dead), which may be an influence on shell radiocarbon concentrations if there is dissolution of the rock in the spray zone into a form which could be taken up by a living shellfish, such as the bicarbonate ion.

There is also the question of post-depositional contamination. The principal contaminant is likely to be dissolved carbonate which recrystallizes onto the surface of archaeological shell within a site. If that dissolved carbonate is of significantly different age then the radiocarbon age will be affected. One test for this contamination is to use powder X-Ray Diffractometry (XRD) to determine the crystallinity of the prehistoric samples. Since carbonate from post-depositional environments precipitates in the form of calcite, the presence of calcite in a naturally secreting aragonitic organism is a good test of recrystallization.

We collected modern samples of Nerita atramentosa and analysed their shell carbonate structures using XRD to determine their natural crystallinity. The samples were both calcite and aragonite, as were the prehistoric examples. This presents problems for determining isotopic exchange postdepositionally for the reasons outlined above.

There is some information in the literature regarding calcareous substrates and their influence on radiocarbon dating samples of archaeological marine and estuarine shell. Dye (1994), for instance, obtained radiocarbon determinations which yielded considerable variation between species of shell of known-age collected from the Hawaiian Islands. Some of the dated shells are of the same genus (Nerita sp.) as those from Norfolk Island, and just as common amongst

Table 6. Group C radiocarbon determinations from Emily Bay and Cemetery Bay.

\begin{tabular}{rlllll}
\hline lab number & Site/Trench & Square/Spit/Unit & CRA(B.P.) & $\mathcal{\delta}^{13} \mathrm{C}$ & calibrated 1 SD (A.D.) \\
\hline I-11019 & Cemetery Bay & Unit C4 & $715 \pm 75$ & - & $1261-1307,1360-1379$ \\
I-11303 & Cemetery Bay & Unit C4 & $840 \pm 160$ & - & $1022-1298$ \\
Beta-6821 & Cemetery Bay & Unit C4 & $850 \pm 50$ & - & $1165-1255$ \\
Beta-6822 & Cemetery Bay & Unit C4 & $800 \pm 50$ & - & $1217-1282$ \\
ANU-10160 & EB95:06 & Square A2 Spit 1 & $390 \pm 70$ & $-24 \pm 2$ & $1443-1634$ \\
ANU-10159 & EB95:06 & Square A3 Spit 2 & $880 \pm 60$ & $-24 \pm 2$ & $1049-1228$ \\
ANU-10157 & EB95:06 & Square A4 Spit 2 & $480 \pm 70$ & $-24 \pm 2$ & $1396-1614$ \\
ANU-10158 & EB95:06 & Square A4 Spit 3 & $810 \pm 70$ & $-24 \pm 2$ & $1185-1284$ \\
WK-6900 & EB97:23 & Square E12 Spit 2 & $320 \pm 45$ & $-21.5 \pm 0.2$ & $1489-1605,1613-1649$ \\
ANU-11195 & EB97:24 & Square A1 Spit 3 & $700 \pm 60$ & $-24 \pm 2$ & $1279-1307,1360-1379$ \\
WK-7821 & EB97:24 & Square A5 Spit 3 & $810 \pm 45$ & $-24.3 \pm 0.2$ & $1215-1280$ \\
ANU-11170 & EB97:24 & Square A5 Spit 2 & $690 \pm 60$ & $-24.2 \pm 2$ & $1281-1310,1353-1386$ \\
ANU-11171 & EB97:24 & Square B4 Spit 2 & $970 \pm 60$ & $-24 \pm 2$ & $1013-1162$ \\
\hline a & & & & \\
b & & &
\end{tabular}


Table 7. Radiocarbon determinations on shell samples from Emily Bay.

\begin{tabular}{clcccc}
\hline lab number & Site/Trench & location & CRA(B.P.) & $\delta^{13} \mathrm{C}$ & calibrated 1 SD (A.D.) \\
& & & & \\
WK-7299 & Pt Ross & basaltic substrate & $112.8 \pm 0.6 \% \mathrm{M}$ & $1.2 \pm 0.2$ & \\
WK-7298 & Cemetery Bay & calcareous substrate & $105 \pm 0.5 \% \mathrm{M}$ & $3.4 \pm 0.2$ & \\
WK-6898 & EB96:10 & Square A2 Spit 1 & $1,380 \pm 50$ & $3.5 \pm 0.2$ & $640-677$ \\
WK-6897 & EB96:10 & Square A4 Spit 1 & $1,440 \pm 45$ & $3.7 \pm 0.2$ & $601-656$ \\
WK-6894 & EB97:23 & Square D10 Spit 5 & $1,510 \pm 45$ & $3.9 \pm 0.2$ & $539-616$ \\
WK-6899 & EB97:23 & Square F12 Spit 3 & $1,480 \pm 50$ & $4.2 \pm 0.2$ & $547-641$ \\
WK-6896 & EB97:24 & Square A3 Spit 1 & $1,420 \pm 45$ & $4.1 \pm 0.2$ & $612-662$ \\
WK-6895 & EB97:24 & Square A5 Spit 2 & $1,560 \pm 45$ & $4.0 \pm 0.2$ & $424-560$ \\
\hline
\end{tabular}

prehistoric midden contexts. Dated Nerita samples yielded apparent ages up to 1740 years older than paired charcoal samples. Dye (1994) suggested that the most important variable in determining apparent ages was the substrate of the shell samples because freshwater inputs were negligible in their influence. Older shell determinations were consistently from locations with limestone substrates and younger determinations were from sites with volcanic substrates. Dye (1994) concluded that old carbon from limestone sources was making its way either indirectly into the organism's carbonate through consuming algae which ingested the limestone, or directly by the molluscs scraping and dissolving the limestone as they browse.

Goodfriend and Hood (1983) have examined ${ }^{14} \mathrm{C}$ uptake in landsnails in Jamaica and the United States. They showed that limestone was a source for shell carbonate in these species and that limestone contributed to carbon building in this organism, along with terrestrial plant carbon and atmospheric $\mathrm{CO}_{2}$. Inputs from limestone-derived carbon occur through dissolution by secretions in the foot of the organism and subsequent metabolic uptake. In addition, limestone nodules may be stored in landsnails in the digestive gland and foot, and dissolved in the gut with subsequent diffusion into the hemolymph where it may then be incorporated into the shell of the organism. The $\delta^{13} \mathrm{C}$ value for land snail is c. 9-10\%o, so the uptake of limestone-derived carbon may be identified from an analysis of the change in $\delta^{13} \mathrm{C}$. Marine gastropods are very different organisms, but it seems reasonable to hypothesize that the mechanism for uptake in Nerita might involve the weathering of $\mathrm{CaCO}_{3}$ from limestone into calcium bicarbonate under localized conditions through foot secretions, with subsequent incorporation into the shell.

We tested this hypothesis by dating post-bomb samples of Nerita of known-age, collected in 1999 from two different substrates; calcareous sandstone and basalt. The results were $105 \pm 0.5 \mathrm{pMC}^{1}$ for the calcareous substrate sample (Wk$7298)$ and $112.8 \pm 0.6 \mathrm{pMC}(\mathrm{Wk}-7299)$ for the basalt substrate. The results are clearly different, with the calcareous substrate sample yielding a lower pMC result and a $\delta^{13} \mathrm{C}$ which mirrors those of the prehistoric samples. It is difficult to determine precisely the size of the offset from "true" age if the pre-bomb Nerita samples are taking up dead carbon from the calcreted sandstone substrate. If we estimate that there is a $7 \%$ contribution from the ${ }^{14} \mathrm{C}$ free source, as the modern determinations imply, and we assume that the reservoir effect for Norfolk Island is the same as the average for the world ocean, then as a first approximation the net reservoir effect locally could amount to 800-1000 years. We think there is a possibility, then, that the older than expected ages might be caused by uptake of carbon from the local ${ }^{14} \mathrm{C}$-free source based on the evidence to hand. The shell determinations of Nerita therefore appear to represent apparent ages too old by between 500 and 600 years. These conclusions might have implications for dating this species in other Pacific contexts, particularly where there is evidence for calcareous rock formations within the environs of the site. The application of a correction to these determinations would be premature and will remain so until additional data are obtained which tests the reliability of our estimated age offset in the Nerita samples. The shell determinations in Table 7 are therefore shown as uncorrected conventional radiocarbon ages (CRA) B.P.

\section{Radiocarbon determinations on bone samples}

Radiocarbon determinations on bone samples are listed in Table 8 . The human bone sample was reported by Specht (1993: 152). Two fractions were dated as follows: ANU$7651 \mathrm{~A}$ (apatite) 460 160 B.P. and ANU-7651B (collagen) $380 \pm 60$ B.P. This sample is from burial 608 at Emily Bay, one of several burials exposed by high seas in 1936 (Specht, 1984: 32). Bulbeck and Groves (1984: 62) concluded that the morphology of the remains "eludes a straight racial identification [and] may well suggest a European $\times$ Oceanic hybrid status" of which they thought Polynesian characters the more prominent. However, the radiocarbon determination, even at two sigma (cal A.D. 1430-1654) is still comfortably older than European discovery. Perhaps this was a Polynesian burial.

There is a degree of uncertainty as well about the interpretation of the AMS determination, OxA-8749, upon the dog mandible (Smith, Clark and White, this vol.), which crosses the prehistoric/historical boundary. The sample was recovered by workmen digging a toilet pit outside the site and although other material collected then appears to be midden, the provenance is insecure. However, since a dog carnassial tooth was found in Trench EB96:11 within the site, the existence of dog prehistorically is probable. The pig mandible (OxA-8750, Smith, Clark and White, this vol.) is certainly modern. It came from the surface spit (1) of the cultural layer of Trench EB97:23 and it suggests, as does

\footnotetext{
1 pMC is percent modern carbon, a ratio of the activity of the modern standard and the unknown sample activity as a percentage. 0 pMC is A.D. 1950.
} 
Table 8. Radiocarbon determinations on bone samples from Emily Bay.

\begin{tabular}{rlccccl}
\hline lab number & Site/Trench & location & material & CRA (B.P.) & $\delta^{13}$ C & calibrated 1SD (A.D.) \\
\hline ANU-7651 & Emily Bay & eroded shore & human bone & $380 \pm 60$ & & $1446-1635$ \\
OxA-8749 & West Emily Bay & 0.8 m below surface & $\begin{array}{c}\text { canine mandible } \\
\text { pig mandible }\end{array}$ & $205 \pm 40$ & -12.7 & $1658-1682,1747-1805,1935-1954$ \\
OxA-8750 & EB97:23 & Spit 1 & pren & -20.9 & $1900-1900,1955$ \\
OxA-5781 & Cemetery Bay & Unit C4 & rat mandible & $495 \pm 55$ & -19.2 & $1320-1460$ \\
NZA-6635 & CB95:01 & Layer 7 & rat femur & $1,077 \pm 79$ & -19.1 & $883-1067$ \\
OZC-697 & CB95:01 & Layer 7 & rat femur & $795 \pm 50$ & -18.3 & $1219-1283$ \\
OZC-699 & EB95:06 & Square A4 Spit 3 & rat tibia & $540 \pm 50$ & -20 & $1398-1434$ \\
NZA-6634 & EB95:06 & Square A4 Spit 1 & rat tibia & $1,206 \pm 94$ & -19.8 & $716-957$ \\
NZA-6631 & EB95:06 & Square A4 Spit 3 & rat femur & $1,142 \pm 86$ & -19.3 & $812-992$ \\
NZA-6630 & EB95:06 & Square A4 Spit 4 & rat mandible & $874 \pm 84$ & -19.3 & $1047-1244$ \\
OZD-833 & EB95:06 & Square A3 Spit 2 & rat femur & $600 \pm 50$ & -20.5 & $1305-1408$ \\
OZD-834 & EB95:06 & Square A1 Spit 2 & rat femur & $605 \pm 45$ & -17.9 & $1305-1405$ \\
NZA-8039 & EB96:10 & Cultural layer Spit 1 & rat bone powder & $552 \pm 50$ & -18.5 & $1326-1430$ \\
OxA-7953 & EB96:10 & Cultural layer Spit 1 & rat bone powder & $565 \pm 45$ & -18.7 & $1321-1421$ \\
OZD-105 & EB96:10 & Cultural layer Spit 1 & rat bone powder & $990 \pm 60$ & -20 & $1004-1156$ \\
OZD-975 & EB96:10 & Cultural layer Spit 1 & rat bone powder & $560 \pm 60$ & -18.9 & $1315-1431$ \\
Ua-14267 & EB97:23 & Square F7 Spit 1 & rat femur & $485 \pm 60$ & -19.7 & $1408-1451$ \\
OxA-8331 & EB97:23 & Square H1 Spit 1 & rat femur & $790 \pm 35$ & -18.3 & $1227-1282$ \\
Ua-14268 & EB97:24 & Square B3 Spit 3 & rat femur & $485 \pm 60$ & -19.7 & $1408-1451$ \\
\hline
\end{tabular}

some other material, that parts of the site had been exposed in the historical period.

All the remaining results are AMS determinations on whole or powdered bone from Rattus exulans. Radiocarbon dating of Rattus exulans bone, including of the Norfolk Island samples (Holdaway and Anderson, 1998) processed by the Rafter Laboratory in Lower Hutt, New Zealand (the NZA series), has been the subject of considerable debate (e.g., Anderson, 1996, 1997, 1998, 2000a; Smith and Anderson, 1998; Holdaway, 1996, 1999; Holdaway and Beavan, 1999) which need not be detailed here. Suffice it to say that the latest review of the data (Anderson, 2000a), argues that there is a strong correlation between unusually old radiocarbon determinations and the period of processing at the Rafter Laboratory. The Norfolk Island results (NZA$6630,6631,6634,6635$, Table 8) were processed in 19951996, during which all the anomalously old determinations on Rattus exulans samples from New Zealand were also produced. Consequently, they should not be regarded as reliable estimates of age.

Part of the process of testing radiocarbon ages on Rattus exulans samples involved inter-laboratory dating of aliquots from the same bone powder samples. The results NZA8039, OxA-7953, OZD-105 and OZD-975 (all Table 8) are from this project. The first was processed at the Rafter Laboratory in 1997-1998 at a time when all rat bone samples produced ages consistent with archaeological expectations (Anderson, 2000a). Sample OZD-105 is one of several anomalously old results from early processing of Rattus exulans samples at the ANSTO Laboratory (Lucas Heights, NSW; series OZC, OZD). A second aliquot subsequently produced the result OZD-975 and the former result is regarded by ANSTO as unreliable. When the unreliable results are discarded it can be seen the remaining determinations from all laboratories are consistent with ages on other material types at about 600 years.

\section{Distribution of radiocarbon determinations}

The radiocarbon determinations do not indicate any differentiation in occupation age between trenches. The Bayesian analysis suggested that Trench EB97:23 area was most probably occupied A.D. 1220-1410 and EB97:24 area for about a century beginning soon after A.D. 1300. On Group B samples and other results, EB97:24 looks to be somewhat earlier, probably occupied in the thirteenth century A.D. Certainly, the distribution of Raoul Island obsidian through Trenches EB97:23 and EB97:24 indicates their general contemporaneity (Turner, Anderson and Fullagar, this vol.). The other main excavation, Trench EB96:10, produced determinations indicative of thirteenth century occupation, and while determinations are few and variable for other parts of the Emily Bay site, they do not contradict the proposition that habitation began in the thirteenth century A.D.

From the first results, referring to Trench EB95:06, it was apparent that there is no significant relationship of age determination with stratigraphy. The Emily Bay site is consistently shallow and disturbed, both by cultural activity at the time of occupation and by subsequent bioturbation, if not other factors as well. It is therefore impossible to test stratigraphically the occupation spans suggested by the Bayesian analyses, and alternative explanations cannot be ranked. Within the 100-200 year occupations suggested, sources of radiocarbon dating variability, not least in inbuilt age of materials, constitute a sufficient explanation, and certainly the low density and shallow depth of material everywhere in the site does not suggest that people were living at Emily Bay for more than a few decades at most. However, we must not lose sight of the fact that occupation on a similar scale to Emily Bay had probably once existed in Slaughter Bay, judging by the continuing recovery of adzes in the intertidal zone there, and that some occupation 
may have extended to, or occurred in, Cemetery Bay, not to mention other places where artefacts have been discovered on Norfolk Island. So, it is quite possible that Emily Bay, while not occupied continuously for 200 years, was frequently visited over a longer period than that in which it was inhabited most intensively.

The determinations from Cemetery Bay are fewer and none are on Group A or B charcoals, so they may have quite significant inbuilt age. Taking that possibility into account, an occupation span beginning in or about the thirteenth century A.D. (c. 800 years B.P.) seems probable. In summary, the prehistoric habitation of Norfolk Island probably began in the early thirteenth century A.D. and may have persisted until the fifteenth century (c. 600 years B.P.) or even later, as some results that are potentially of cultural origin suggest the sixteenth and early seventeenth centuries.

\section{The Norfolk Island chronology in Pacific perspective}

The Norfolk Island archaeological chronology is strikingly similar to that from elsewhere in the south Polynesian region (Anderson, 2000b). Assemblages of radiocarbon determinations have shown, contrary to some earlier evidence and conjecture, that the earliest-known archaeological sites in New Zealand were inhabited from the thirteenth century A.D., as notably at Papatowai (Anderson and Smith, 1992), Houhora (Anderson and Wallace, 1993) and Wairau Bar (Higham et al., 1999). Extensive radiocarbon databases compiled by the Rafter Radiocarbon Laboratory (Anderson, 1991) and the Waikato Radiocarbon Laboratory (Higham, 1993; Higham and Hogg, 1997), as well as a wide-ranging study of the calibrated ages (McFadgen et al., 1994), agree that there is no evidence of human habitation of New Zealand before 800-600 B.P.

An extensive colonization site on Raoul Island in the Kermadecs, discovered in 1979 (Anderson, 1980), has radiocarbon dates extending back to 1,000 B.P., but probably because the first set of charcoal samples were exclusively on charcoal from the long-lived pohutukawa tree, Metrosideros sp. Later research, using different sample materials, indicated that $650-600$ B.P. was a better estimate of the advent of habitation (Higham and Johnson, 1996). A similar age, 800-600 B.P., is indicated on relatively short life span charcoals (Phyllocladus sp.) from a fireplace and associated midden at Sandy Bay, on Enderby Island in the New Zealand subantarctic region. In short, south Polynesia was settled at virtually the same time and very probably from within the same colonizing population out of central East Polynesia. The Norfolk Island chronology fits precisely into this pattern.

\section{References}

Anderson, A.J., 1980. The archaeology of Raoul Island (Kermadecs) and its place in the settlement history of Polynesia. Archaeology and Physical Anthropology in Oceania 15: 131141.

Anderson, A.J., 1991. The chronology of colonization in New Zealand. Antiquity 65: 767-795.

Anderson, A.J., 1996. Was Rattus exulans in New Zealand 2000 years ago? AMS radiocarbon ages from Shag River Mouth. Archaeology in Oceania 31: 178-184.
Anderson, A.J., 1997. The dating of Rattus exulans bones-further discussion. Journal of the Polynesian Society 106: 312-313.

Anderson, A.J., 1998. Reply to comments on "A production trend in AMS ages on Rattus exulans bone." Archaeology in New Zealand 41: 231-234.

Anderson, A.J., 2000a. Differential reliability of ${ }^{14} \mathrm{C}$ AMS ages of Rattus exulans bone gelatin in south Pacific prehistory. Journal of the Royal Society of New Zealand 30: 243-261.

Anderson, A.J., 2000b. The advent chronology of south Polynesia. In Essays in Honour of Arne Skjølsvold, 75 years, ed. P. Wallin and H. Martinsson-Wallin. Occasional Papers of the Kon-Tiki Museum 5: 73-82.

Anderson, A.J., and I.W.G. Smith, 1992. The Papatowai Site: new evidence and interpretations. Journal of the Polynesian Society 101: 129-158.

Anderson, A.J., and R.T. Wallace, 1993. Radiocarbon chronology of the Houhora site, Northland, New Zealand. New Zealand Journal of Archaeology 15: 5-16.

Buck, C.E., W.G. Cavanagh and C.D. Litton, 1996. Bayesian approach to interpreting archaeological data. London: John Wiley and Sons.

Buck, C.E., J.A. Christen and G.N. James, 1999. BCal: an online Bayesian radiocarbon calibration tool. Internet Archaeology 7.

http://intarch.ac.uk/journal/issue7/buck_index.html

Bulbeck, F.D., and C.P. Groves, 1984. Appendix II. Skeletal remains from grave 608. In The Prehistoric Archaeology of Norfolk Island, ed. J. Specht, pp. 57-74. Pacific Anthropological Records 34. Honolulu: Bernice P. Bishop Museum.

Dye, T., 1994. Apparent ages of marine shells: implications for archaeological dating in Hawai'i. Radiocarbon 36: 51-57.

Goodfriend G.A., and D.G. Hood, 1983. Carbon isotope analysis of land snail shells: implications for carbon sources and radiocarbon dating. Radiocarbon 25: 810-830.

Higham, T.F.G., 1993. Radiocarbon Dating the Prehistory of New Zealand. Unpublished PhD thesis, University of Waikato, Hamilton.

Higham, T.F.G., and A.G. Hogg, 1997. Evidence for late Polynesian colonization of New Zealand: University of Waikato radiocarbon measurements. Radiocarbon 39: 149-192.

Higham, T.F.G., and L. Johnson, 1996. The prehistoric chronology of Raoul Island, the Kermadec Group. Archaeology in Oceania 31: 207-213.

Higham, T.F.G., A.J. Anderson and C. Jacomb, 1999. Dating the first New Zealanders: the chronology of Wairau Bar. Antiquity 73: 420-427.

Holdaway, R.N., 1996. The arrival of rats in New Zealand. Nature 384: 225-226.

Holdaway, R.N., 1999. A spatio-temporal model for the invasion of the New Zealand archipelago by the Pacific rat Rattus exulans. Journal of the Royal Society of New Zealand 29: 91-105.

Holdaway, R.N., and A.J. Anderson, 1998. ${ }^{14}$ C AMS dates on Rattus exulans bones from natural and archaeological contexts on Norfolk Island, South-west Pacific. Archaeology in New Zealand 41: 195-198.

Holdaway, R.N., and N.R. Beavan, 1999. Reliable ${ }^{14}$ C AMS dates on bird and Pacific rat Rattus exulans bone gelatin, from a $\mathrm{CaCO}_{3}$-rich deposit. Journal of the Royal Society of New Zealand 29: 185-211.

McFadgen, B.G., 1982. Dating New Zealand archaeology by radiocarbon. New Zealand Journal of Science 25: 379-392.

McFadgen, B.G., F.B. Knox and T.R.L. Cole, 1994. Radiocarbon calibration curve variations and their implications for the interpretation of New Zealand prehistory. Radiocarbon 36: 221-236.

Meredith, C.W., 1985. The Fossil Fauna of Norfolk Island, Southwest Pacific, and a Review of the Phylogeny of the Genus Pterodroma. Unpublished PhD thesis, Department of Zoology, 
Monash University, Clayton, Victoria, Australia.

Orchard, A.E., \& H.S. Thompson, 1999. Flora of Australia. Volume 49, Oceanic Islands 1, 2nd ed. Canberra: Australian Government Publishing Service.

Rich, P., G. van Tets, K. Orth, C. Meredith and P. Davidson, 1983. Prehistory of the Norfolk Island biota. In A Review of Norfolk Island Birds: Past and Present, ed. R. Schodde, P. Fullagar and N. Hermes, pp. 7-29. Australian National Parks \& Wildlife Service, Special Publication 8. Canberra: Australian National Parks \& Wildlife Service.

Smith, I.W.G., and A.J. Anderson, 1998. Radiocarbon dates from archaeological rat bone: the Pleasant River case. Archaeology in Oceania 33: 88-91.
Specht, J., 1984. The Prehistoric Archaeology of Norfolk Island. Pacific Anthropological Records 34. Honolulu: Bernice P. Bishop Museum.

Specht, J., 1993. Additional evidence for pre-1788 visits by Pacific Islanders to Norfolk Island, South-west Pacific. Records of the Australian Museum, Supplement 17: 145-157.

Stuiver, M., P.J. Reimer, E. Bard, J.W. Beck, G.S. Burr, K.A. Hughen, B. Kromer, F.G. McCormac, J.v.d. Plicht and M. Spurk, 1998. INTCAL98 Radiocarbon age calibration, 240000 cal A.D. Radiocarbon 40: 1041-1083.

Wallace, R.T., 1998. Norfolk Island Prehistory Project: Charcoal Identifications and Dating Sample Selection. Unpublished report, Anthropology Department, University of Auckland. 
Full-text PDF of each one of the works in this volume are available at the following links :

Anderson and White, vol. eds, 2001, Rec. Aust. Mus., Suppl. 27: 1-143

http://dx.doi.org/10.3853/j.0812-7387.27.2001.1334

Anderson and White, 2001, Rec. Aust. Mus., Suppl. 27: 1-9

http://dx.doi.org/10.3853/j.0812-7387.27.2001.1335

Anderson et al., 2001, Rec. Aust. Mus., Suppl. 27: 11-32

http://dx.doi.org/10.3853/j.0812-7387.27.2001.1336

Anderson et al., 2001, Rec. Aust. Mus., Suppl. 27: 33-42

http://dx.doi.org/10.3853/j.0812-7387.27.2001.1337

Anderson and Green, 2001, Rec. Aust. Mus., Suppl. 27: 43-51

http://dx.doi.org/10.3853/j.0812-7387.27.2001.1338

Marianne et al., 2001, Rec. Aust. Mus., Suppl. 27: 53-66

http://dx.doi.org/10.3853/j.0812-7387.27.2001.1339

Schmidt et al., 2001, Rec. Aust. Mus., Suppl. 27: 67-74

http://dx.doi.org/10.3853/j.0812-7387.27.2001.1340

Smith et al., 2001, Rec. Aust. Mus., Suppl. 27: 75-79

http://dx.doi.org/10.3853/j.0812-7387.27.2001.1341

Matisoo-Smith et al., 2001, Rec. Aust. Mus., Suppl. 27: 81-84

http://dx.doi.org/10.3853/j.0812-7387.27.2001.1342

Holdaway and Anderson, 2001, Rec. Aust. Mus., Suppl. 27: 85-100

http://dx.doi.org/10.3853/j.0812-7387.27.2001.1343

Walter and Anderson, 2001, Rec. Aust. Mus., Suppl. 27: 101-108

http://dx.doi.org/10.3853/j.0812-7387.27.2001.1344

Campbell and Schmidt, 2001, Rec. Aust. Mus., Suppl. 27: 109-114

http://dx.doi.org/10.3853/j.0812-7387.27.2001.1345

Neuweger et al., 2001, Rec. Aust. Mus., Suppl. 27: 115-122

http://dx.doi.org/10.3853/j.0812-7387.27.2001.1346

Macphail et al., 2001, Rec. Aust. Mus., Suppl. 27: 123-134

http://dx.doi.org/10.3853/j.0812-7387.27.2001.1347

Anderson and White, 2001, Rec. Aust. Mus., Suppl. 27: 135-141

http://dx.doi.org/10.3853/j.0812-7387.27.2001.1348 